\title{
An Inquiry into the Impact of Information and Communication Technologies (ICTs) on the Enrolment, Registration, Examination Clearance and Access to Results of Students at Africa University, Mutare, Zimbabwe
}

\author{
Stanislas Bigirimana \\ sbigirimanaus@yahoo.com \\ Prof Nelson Jagero,Phd \\ Faculty of Human Resource Development and Education \\ Chuka University, PO BOX 109 Chuka Kenya \\ Edna Daudi \\ Department of Distance Education \\ Africa University, PO BOX 1320 Mutare, Zimbabwe
}

\begin{abstract}
A descriptive survey was undertaken to assess the impact of the use of ICTs in the management of administrative tasks at at Africa University. The focus was on students' enrolment, registration and examination clearance. It was found that during these procedures long queues are the order of the day. Students are very dissatisfied with these processes that they described as "cumbersome." Reasons militating for this situation include lack of skilled manpower, resistance to change, and and low employee morale. This study recommended that an integrated system be put in place and that holistic approach to service provision be instituted.
\end{abstract}

\section{INTRODUCTION}

Information and Communication Technology (ICT) is a generic that defines or refers to technologies used to for collecting, storing, editing, and passing information in various forms (Jager and Lokman; 1999). Currently, Information and Communication Technologies (ICTs) are associated with the unprecedented development of electronic computers and other devices that use microprocessors. Freedman (2002) is of the view that a lot of administrative burdens can be relieved by using ICTs wisely. He lists activities such as examinations entry, registration of students, informing people, scheduling, data analysis, lesson plans and preparation, timetabling, publicity and image, diaries, departmental handbooks, budget and capitation as areas where ICTs can make an unprecedented impact. Penrod (2003) believes that Information Technology (IT) should impact the daily operations and functions of a university. ICTs should relate directly to the mission of the institution.

An administrative system houses an institution's core data and enables staff to execute the processes that support the business of education such as student registration, applications processing, payroll, etc. (Moul; 2003). One of the areas of concern facing higher education is the ever changing environment, it is important that ICT optimizes the ability of institutions to respond to the new environment (Guan, Nunez, and Welsh; 2002). It is therefore imperative that ICTs enhance clerical and managerial productivity in offices across campus through the 
use of electronic mail, file transfer protocols, visuals and other multimedia features. Hicks (1993: 192) identifies three basic types of communication i.e. voice, text and image (graphics, pictures, drawings and moving video images). Activities that occur in an office include managing documents, managing schedules for individuals and groups, managing projects, communicating with groups and individuals, managing data and managing decisions. ICTs can be applied to automate and quicken all these activities.

\section{Research Problem}

Newmann (1994) indicated that ICTs provide tools for data collection, analysis, storage and dissemination to support decision-making in organizations. Despite the fact that every administrative employee at Africa University has a computer at his or her desk, Africa University students still experience long queues during the registration and examination clearance procedures. Most of these processes are still done manually although Africa University has state of the arts equipment. This study sought to assess the reasons ICTs at Africa University are not producing the results anticipated in existing literature on the impact of ICTs on the management of administrative tasks.

\section{Research Objectives}

1. To assess whether Information and Communication Technologies (ICTs) are being used effectively and efficiently in performing administrative tasks such as student registration and examination clearance.

2. To identify reasons militating for the prevailing situation where during end of semester evaluations and informal communications students expressed dissatisfaction with the current level of service provision.

\section{LITERATURE REVIEW}

Information and Communication Technology (ICT) plays a vital role the management of administrative tasks in the higher education sector. According to Maki (2008), administrative subsystems include personnel administration, student administration, resources administration, financial administration and general administration. According to Ben-Zion Barta et al. (1995) the following areas are suitable for the use of ICTs: general Administration, Payroll and financial accounting, administration of students data, inventory management, personnel records, maintenance, and library systems. Blunt (1990) referred to institutional administration as all those activities carried out to provide for both the long-range viability of the institutional administration is to promote efficiency, consistency, and continuity.

As Salerno (2009) has indicated, the various ways of introducing information and communication technologies (ICTs) in education institution administration include: (1) sending e-mail notices and agendas to staff, rather than printing and distributing them; (2) submission of lesson plans through e-mail; (3) foster technology growth by asking parents to write e-mail addresses on medical forms; (4) insist that all teachers create a class Web page; (5) attend technology conferences to see what other schools are doing, what other teachers are doing to integrate technology, and what principals are doing to encourage the use of technology in their schools and classrooms; (6) admissions through web-enabled services; (7) all day-to-day activities of the institution (General Administration); and (8) staff administration.

The use of information and communication technologies (ICTs) in the administration of institutions of higher education is also necessitated by the kind of students that universities are currently enrolling. A new generation of learners is entering universities. These are the 'digital natives' or 'Net Generation' (Tapscott, 1999; Prensky, 2001; Oblinger, 2003). Born in the 1980s and the 1990s, these young people been immersed in information and 
communication technologies (ICTs) as an integral part of their everyday lives. Digital natives learn differently from past generations of students. They are active experiential learners rather than passive recipients of didactic teaching, proficient in multi-tasking, and dependent on communications technologies for accessing information and for interacting with others (Tapscott, 1999; Frand, 2000; Prensky, 2001; Oblinger \& Oblinger, 2005). In developing country, as Tapscott (1999) has noted 'There is growing appreciation that the old approach [of didactic teaching] is ill-suited to the intellectual, social, motivational, and emotional needs of the new generation'. Kirsti (2005) observed that students today find it easy to pick up any available new electronic device and learn how to communicate with it easily. Though if results could be uploaded on the University website with a fully functional Management Information System (MIS), students would find it easier to access them unlike today where at times the system is down and they have to resort to the notice boards. Recording data electronically, storing it centrally, and sharing it with colleagues are vital to reducing workloads through available ICT structures (Devon, 2004).

The use of ICT in higher education is a global phenomenon (Gordon, 2003). ICTs feature in plans to build and sustain the economy globally (Schunk, 2004). ICTs are considered as an important tool in addressing challenges that institutional of higher learning face (La Rocque \& Latham 2003; Guttmann, 2003). A normative perspective on the use of ICT in higher education is often grounded in the conviction that ICTs necessarily will "change the way a university or college does its core activities or business so that it can reach out to new needs and new target groups" (Bates 2000:57). Stensaker and Skjersli (2002: 112) have criticised this perspective for ignoring the history of higher education institutions, and the interest many universities and colleges have in maintaining and developing their profile and distinct identity even when adapting to new technologies. However, universities face unprecedented challenges linked with increasing students populations, availability of competing online, distance, and noncampus based models and internationalisation of educational systems.

The current flurry of technological innovations has vast implications for college and university recruitment practices (Tyson, 1999). Electronic registration is a secure website that students enter to indicate that they will attend classes in the upcoming semester (Strauss, 2000). Students can access the e-registration site from anywhere with an internet connection. Mostly these sites are portals. Pena-Lopez (2007) describes a web portal as a site that functions as a point of access to information on the World Wide Web and portals present information from diverse sources. It is imperative for institution of higher education to take advantage of the opportunities offered by the unprecedented development and diffusion of electronic computers and related information and communication technologies. Indeed, there is a paradigm shift. Enrolment management helped usher marketing concepts into the admission vocabulary because universities worldwide are no longer perceived as national service providers for development processes but as businesses which have at least to recover their expenses or even make a profit when necessary. That is why public institutions of higher learning have been invited to learn from the private sector.

ICTs in an institutions of higher learning can be applied in various areas. They span across the value chain from recruitment, enrolment, registration, instruction, examination, students data management, and communication. For instance, Geoff, Daniel, Dimitra, and Sue (2006), have noted that electronic registration could play an important role in helping schools with high rates of absence to improve attendance, it saved time. They also noted that ICTs played an important role in lesson monitoring although some schools experienced substantial difficulties. Examination is always an effective instrument to evaluate the quality and quantity of 
knowledge or say learning in a specific field Mishra (1988). Therefore, it is important to use ICTs for examinations administration even when the institution does not offer online examinations.

Any modern institution of higher learning is critically dependent on the smooth operation of Information and Communication Technology (Tusubira, 2005). However, the use of ICTs in the management of administrative tasks in institutions of higher learning depend on infrastructure and its accessibility. Infrastructure includes word processors, electronic databases, e-mail and management information systems, the internet, intranets and portals. (Brakel, 2003). These infrastructure can result in more efficient communications and reduction delays, erros and redundancy (Sibangani, 2006). Brakel (2003) is of the view that end-users can gain effective access to information sources needed to assist in daily tasks such as effective decision making, planning and research. Accessibility to ICT facilities ensures accuracy, timeliness and effectiveness of managing the whole process of examination, that is, it allows easy flow of information and risk monitoring systems that are appropriate (BECTA, 2000).

Devon (2004) points out that in respect to management of students" affairs; there are various types of information systems that can be available in making informed decisions at all levels and in improving efficiency of operations, such as executive decision making management information system, collaborative information systems, electronic messaging systems, group decision support system. These would enable multiparty participation in the University activities through sophisticated information management (Huseman and Miles, 1988). Africa University has heavily invested in information and communication technologies. Most of the university offices are equipped with state of the art computers which are connected to the internet. The university also have a centralised database to manage students records and a wireless internet connection facility. This study sought to investigate the reason why despite these state of art facilities the management of administrative tasks such as enrolment, registration and examination clearance are still characterised by long queues and dissatisfaction by students.

\section{Research Deign}

\section{RESEARCH METHODOLOGY}

This study used a descriptive survey

\section{Population and Sampling Techniques}

Purposive sampling was used. The targeted population included all AU students and all members of staff. A sample of 25 students and 25 members of staff were used.

\section{Research instruments and Data Collection Methods}

Quantitative data was collected using questionnaires while qualitative data was collected through semi-structured interviews and participant observation.

\section{Data Presentation}

The quantitative data collected with questionnaires as tabulated using SPSS while spreadsheets were used to prepare graphics which described variables. Participant observation and semi-structured interviews confirmed the state of dissatisfaction on which this study is premised.

\section{The Efficient Use of ICTs}

\section{FINDINGS}

Figure 5 shows that $60 \%$ of the respondents felt that ICT was not being used efficiently and effectively whilst $40 \%$ felt it was being used effectively. 


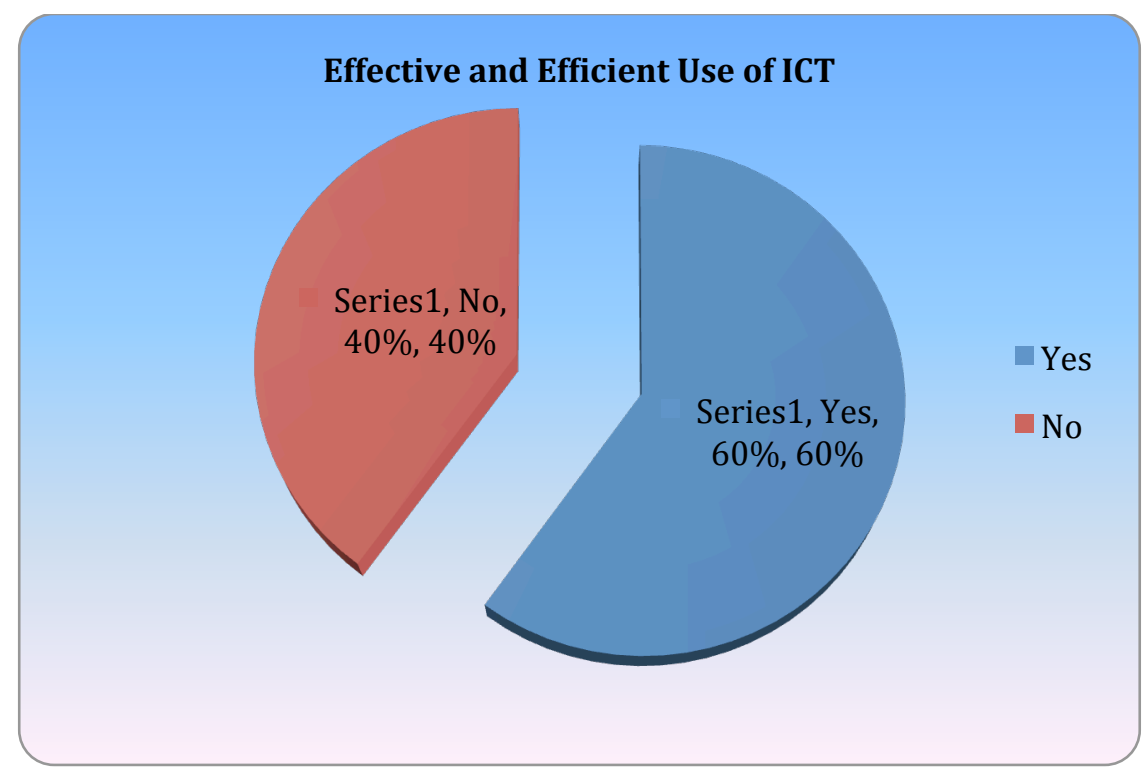

Figure 5: Effective and Efficient Use of ICT

The views of those saying it was not effective seem to agree with Awe's (2000) observations where it was noted that the inefficiency was due to lack of funding and continued power cuts. The same scenario obtains in Zimbabwe where three quarters of the days there will be no power and universities are not spared. Africa University, however, has efficient back up power in the form of generators. The respondents also advanced a number of reasons for their opinions and the findings below outlines the reasons for all the respondents.

Respondents who felt ICT was not being used effectively and efficiently gave the following reasons. Lack of E-Registration was the major point. 23(53.5\%) of the respondents cited that they had to endure long queues in order to register and the process was cumbersome. This is in disagreement with Shanker (2008) who ascertains that the use of ICT in many organizations has assisted in reducing transactional cost, overcome the constraints of distance and have cut across geographic boundaries thereby assisting to improve coordination of activities within organizational boundaries.

Another reason given was that some activities are still being done manually. 21(48.8\%) of the respondents mentioned that they have to move from one office to another of which in many instances it can be avoided by doing things electronically. Examination clearance procedure was stated as inefficient and ineffective and 9(20\%) of the respondents mentioned they again have to endure long queues. These respondents' views seem to concur with Kashyap (1999)'s observation that the goodness of an information system can be best determined by the extent to which it provides for the fulfilment of its users' informational needs and interests.

Resistance to change was another reason advanced by respondents and the reason being that most tasks are still being carried out using traditional ways. However, Borgman (2000) notes that although the advent information or any other new technology makes possible all sorts of new activities, people still find it very difficult to discard old habits and practices. One of the responses was that student results were not available online instantly. $2(4.7 \%)$ of the respondents mentioned that when results are out sometimes the portal will be down most of the time and they end up resorting to travelling to the university to check them on the notice board which was costly for them. 
Another reason given was that access to facilities is still human driven and therefore it was causing inefficiency. This is against (Megan, n.d.) 's view that ICT services were introduced to ensure that services are provided in a much shorter time than previously possible through manual methods. Respondents mentioned that that there was no training for general hands therefore they were unable to use computers. Budget constraints were another reason given and respondents noted that this was why there were no systems in place. Last but not least computer accessories and consumables was least ranked and 2(4.7\%) of the respondents mentioned that there was need to keep stock of computer consumables and accessories all the time to avoid shortages.

\section{Use of ICTs during Registration}

Respondents were asked to indicate the effectiveness of ICT in carrying out administrative tasks among them registration, examination clearance, online results. Fig. 6 indicates that most respondents viewed the registration process at AU a average (41.90\%) whilst 23.30\% considered it as good, $18.60 \%$ as poor, $9.30 \%$ as very poor and $7 \%$ as excellent.

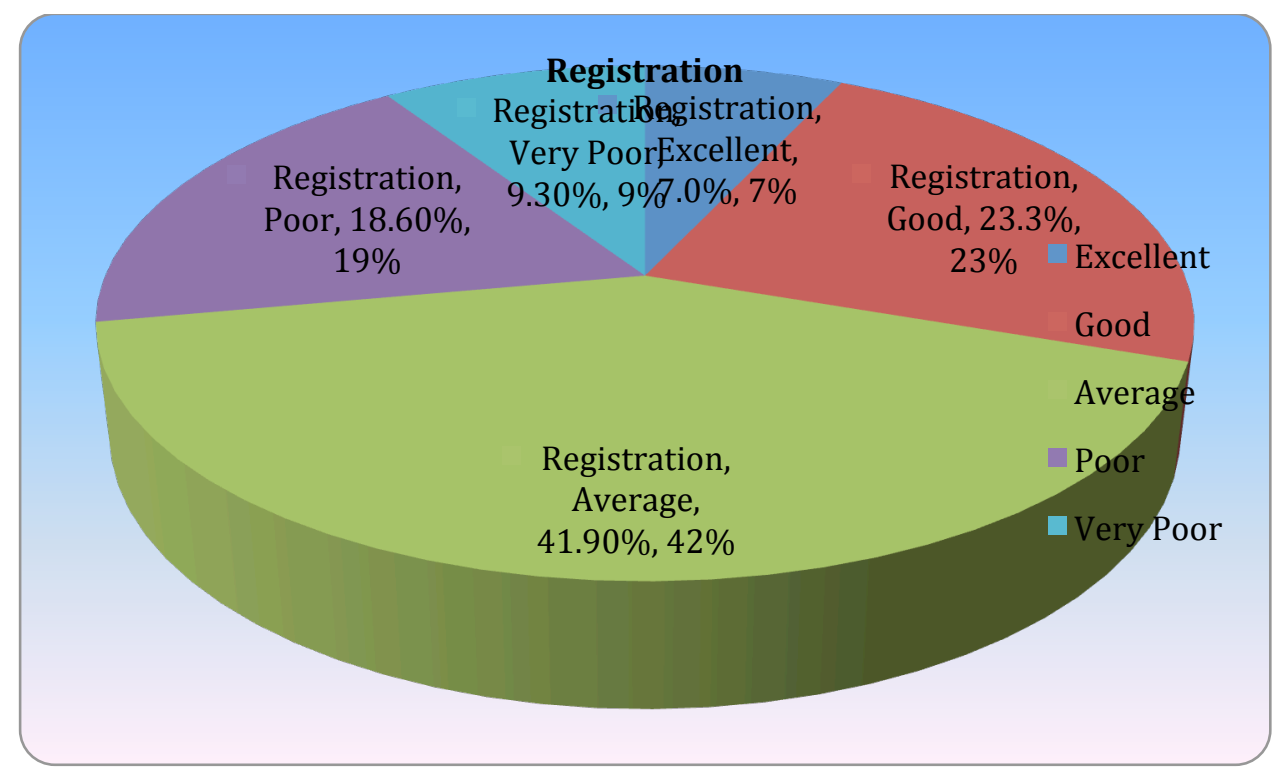

Figure 6: Effectiveness of ICT in Registration

From the study, it was realized that $18(41.90 \%)$ of the students considered the registration process as average whilst $10(23.30 \%)$ rated it good, they all concurred that it needed improvement since long queues were still visible making the process cumbersome. 8(18.60\%) of the respondents stated that it was poor while $4(9.30 \%)$ said it was very poor. They all agreed that the process could be improved by introducing online registration to cater for students who stay far and those who cannot make it on time. This view is supported by PenaLopez (2007) who states that students can access the e-registration site from anywhere with an internet connection. Mostly these sites are portals. $3(7 \%)$ of the respondents mentioned that it was excellent.

\section{Use of ICTs in Examination Clearance}

Fig. 7 indicates that $44.20 \%$ of the respondents viewed the examination clearance process at AU as poor whilst $41.90 \%$ considered it as average , $7 . \%$ regarded it as good, $4.70 \%$ as very poor and $2.3 \%$ as excellent. 


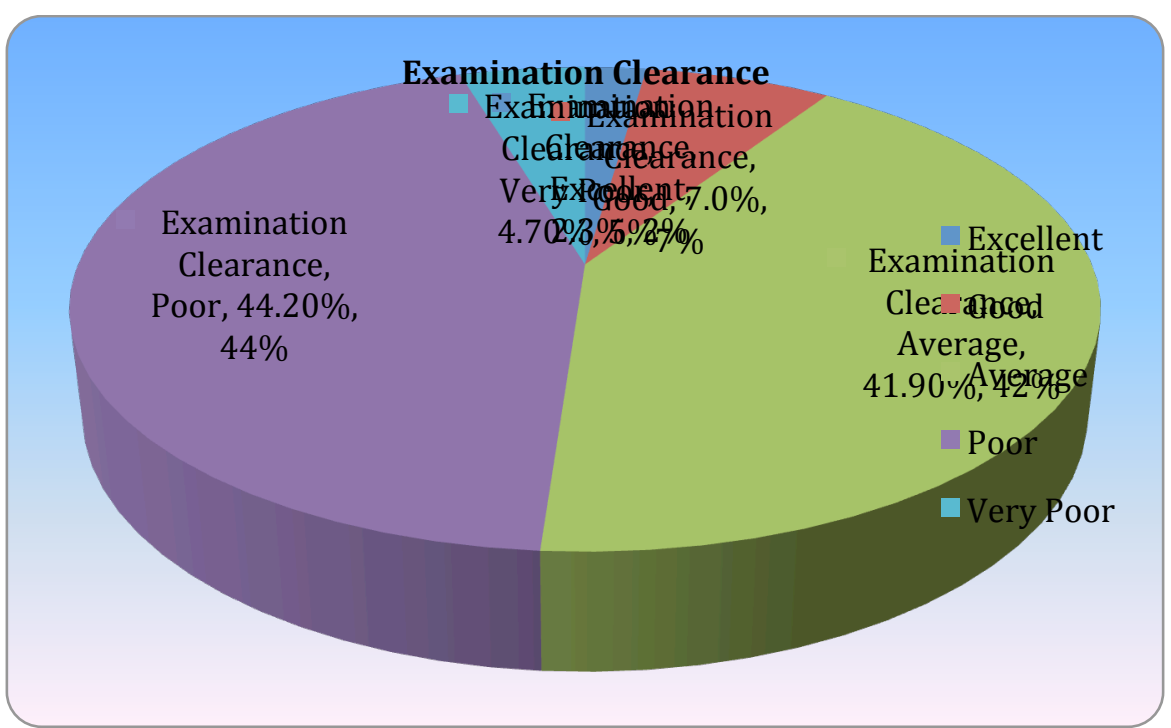

Figure 7: Effectiveness of ICT in Examination Clearance

It has been observed that using ICT will promote issues on students' admission, students' records and transcript, examination records, teaching, research and community services (Abe \& Adu, 2007). However this view goes against the responses given by $19(44.20 \%$ of the respondents who mentioned that AU's ICT was poor because the process of getting examination clearance was cumbersome and time wasting. About $18(41.90 \%)$ of the respondents stated that it was average and just needed improvement by minimizing queues. $3(7 \%)$ of the respondents however felt it was good since it minimized congestion in the exam rooms. $2(4.70 \%)$ of the respondents however felt it was very poor since it was done manually whilst it can be computerized. However $1(2.3 \%)$ of the respondents felt it was excellent as it prevented non registered students from entering the exam room. Students lamented that there is no direct online link between the university accounts office and the bank. 2(4.7\%) of the respondents stated that this was a problem since it takes long for the university to update students accounts.

\section{Use of ICTs in Accessing Results}

Fig. 8 indicates that $51.20 \%$ of the respondents viewed access to online results system at AU as average whilst $32.60 \%$ considered it as poor, $7 \%$ as good, $4.70 \%$ as very poor and $4.70 \%$ viewed it as excellent.

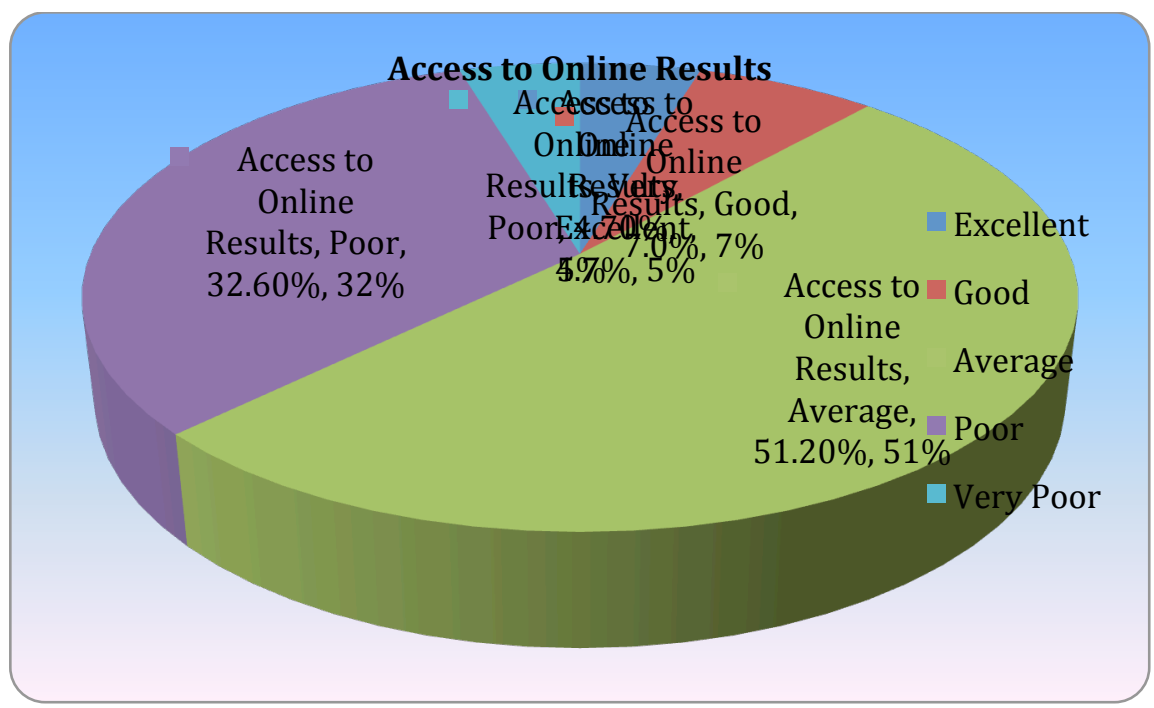

Figure 8: Effectiveness of ICT in accessing online results 
From the diagram above ,22(51.20\%) of the respondents rated access to online results as average but stated that there was still need for improvement. Other respondents rated it as poor $14(32.60 \%)$ and $2(4.70 \%)$ rated it very poor with all citing that sometimes they cannot access them online as the system will be down. Respondents who rated access to online results as good $3(7 \%)$ and excellent $2(4.7 \%)$ gave the same response that it was a wise move as students can now access results without travelling to the university.

\section{CONCLUSION}

The study revealed that ICTs are not being used effectively and efficiently in the university. The major stumbling blocks were given as lack of appreciation of ICTs, resistance to change, lack of skilled workers. The study established that ICTs has been employed in the university to a lesser extent. Many activities are still being done manually including but not limited to enrolment, registration, examination clearance, and access to results. The study revealed that there have been administrative improvements that have resulted from the establishment of ICT. There were mixed feelings as to whether the establishment of ICT has brought any improvements or not. They are however compelling arguments from the other section of the university who strongly felt that ICT has brought noticeable improvement in administrative issues. Their arguments are premised on the observations that a lot of activities are manually done yet there is vast potential for ICT capacity utilization. Africa University needs to optimise the use of current ICTs technologies in all areas of operations in order to maintain efficiency and effectiveness in the management of administrative activities if quality management has to be maintained. A more holistic approach should be adopted which requires that schools be receptive and open to the changes ICTs may make for the schools' purposes The university should introduce an Integrated Information System which supports key administrative and academic services. The core of such a system should support minimal student administration (enrolment procedures and student enrolment, financial support for students, student data), human resource management (monitoring of employees) and finance (accounting, payments, investments, budget). It is possible to include some other programme add-ons, e.g. assets management. At the moment the system is disintegrated. There should be a deliberate and concerted effort in formulating ICT policies that enhances a paradigm shift from paper to chip thereby enhancing improvements in administrative activities. Management should make the university an ICT learning organisation.

\section{References}

Awe, W. (2000). Management Information Systems. Gilgal Publications: Lagos

Ben-Zion Barta,"Information Technology in Educational Management", Chapman and Hall, London, 1995.

Caroline Salerno (2009),"Administrator's Role in Technology Integration", EducationWorld 2009.

Hicks, J. O., (1993) Management information systems: a user perspective. West Publishing: New York

Kashyap, M. (1999), Computer Based Library Information Systems Designing Techniques, Sterling Publishers, New Delhi

LaRocque, Norman and Latham, Michael, 2003, 'The Promise of E-Learning in Africa: The Potential for PublicPrivate Partnerships.' IBM Endowment for the Business of Government.

Mishra, N. L. (1988). Organization and Management of University Examinations, National Publishing House, Jaipur (Raj.), India.

Newmann, S. (1994). Strategic information systems - Competition through information technologies. Macmillan: New York

Schunk, D. H, (2004). Learning Theories: an educational perspective. 4th ed. Pearson Prentice Hall: Upper Saddle River, N. J 
Bigirimana, S., Jagero, N., \& Daudi, E. (2015). An inquiry into the Impact of information and Communication Technologies (ICTs) on the Enrolment, Registration, Examination Clerance and Access to Results of Students at Africa University, Mutare, Zimbabwe. Archives of Business Research, 3(2), $104-113$.

Stensaker, B \& Skjersli, S. (2002); Organising ICT Initiatives in Higher Education: A reflection on the Critical Factors, Three Quality Issues, Eight Contributions on Quality and Flexible Learning, Swedish Agency for Distance Education, Report 1:2002.

Tapscott, D. (1999) Growing up Digital: The Rise of the Net Generation. McGraw-Hill: New York.

Abe, T.O. and Adu, E.T. (2007):Impact of information and Communication Technology (ICT) on Teacher Education in Ikere Journal of Education, Ikere Ekiti. Vol. 5 No. pp. 169-175.

Brakel, Pieter van. (2003) Information portals: a strategy for importing external content, Electronic Library, The, Vol. 21 Iss: 6, pp. 591-600

Christiana Maki (2008),"Information and Communication Technology for Administration and Management for secondary schools in Cyprus", Journal of Online Learning and Teaching Vol. 4 No. 3.

Guan, J., Nunez, W., \& Welsh, J.F., (2002). Institutional Strategy and Information Support: The role of data warehousing in higher education. Campus-Wide Information Systems. 5(19), pp.168-174.

Gordon, M. (2003). Government Intervention: ICT policies around the world. In Beebe, M. et al.(eds). Africa Dot Edu: IT opportunities and higher education in Africa. Tata McGraw-Hill: New Delhi. 113-128

Huseman, R.C and E.W. Miles, (1988), Organizational Communication in the Information Age: Implication of computer-based Systems, Journal of management, 14,2,181-204

Penrod J. (2003) Information systems concepts: a guide for executives, Logistics Information Management Volume 10 Number 4 pp.146-153.

Pena-Lopez, I. (2007) The Personal Research Portal: Web 2.0 Driven Individual commitment with open access development, Knowledge Management for Development Journal, Amsterdam. 3 (1) 35-48.

Tyson, D.C. (1999), "Simple paradigms, simple solutions: how counsellors could lead admission reform”, Journal of College Admission, Vol. 165, Fall, pp. 14-21.

Blunt, P (1990). "Strategies for Enhancing Organizational Effectiveness in Third World". Public Administration and Development: London.

Becta (2000) A Preliminary Report for the DfEE on the Relationship Between ICT and Primary School Standards. http://www.becta.org.uk/research/reports/ictresources.html accessed 5 February 2013

Borgman, C. (2000). The Premise and Promise of a Global Information Infrastructure. First Monday. Online: http://www.firstmonday.org/issues/issue5_8/borgman/. Accessed 3 May 2013

Devon County Council LEA ICT Strategy for schools 2003-2006 (2004)

http://www.devon.gov.uk/ict_strategy_for_schools.pdf

Freedman T. (2002), Managing with ICT, IT in Educational Administration, www.ictineducation.org. (Assessed 28 January 2013)

Kirsti Aho (2005). Teaching Digital Communication to All Students, journal, http://www.adobe.com/resources/education/whitepapers/dc_for_all_students.pdf

Megan. (n.d). The Impact of ICTs on the Design and Delivery of Public Services.Online: http://www.3s4.org.uk/news/the-impact-of-ict-on-the-design-and-delivery-ofpublic- services. Accessed 21 March 2013

Moul B. (2003) Creating a Unified Digital Campus to satisfy the need of 21st Century learners, The Technology Source, www.ts.mivu.org

Strauss, Howard (2000) Tech Talk Event CNI Spring Task Force Meeting, March 27-28. www.cren.net/know/techtalk/events/portals.html

Tusubira F (2005), Supporting University ICT Developments: The Makerere University Experience, http://www.codesria.org

Geoff, L, Daniel. M, Dimitra, H and Sue B, (2006). Evaluation of Capital Modernization Funding for Electronic Registration in Selected Secondary Schools, Centre for Educational Development, Appraisal and Research (CEDAR), University of Warwick, University of Manchester, Institute of Education, Research Report, 
Jager A.K. and Lokman A.H (1999). Impact of ICT in education. The Role of the teacher and teacher training. Stoas Research, Wageningen, The Netherlands, European Conference on Educational Research, Finland.

Sibangani G (2006) ICT and Administrative Efficiency.... A Case for NSSA Zimbabwe Presented in Seychelles

Bates, A.W. (2000). Managing Technological Change: Strategies for College and University Leaders. San Francisco: Jossey-Bass. Collis, B. (1999). 'Pedagogical perspectives on ICT use

Shanker, D. (2008). ICT and Tourism: Challenges and Opportunities. Conference on Tourism in India - Challenges Ahead, 15-17 May 2008, IIML. 